\title{
Anti-inflammatory and Anti-arthritic Activities of Glycosylated Flavonoids from Syzygium jambos in Edematogenic Agent-Induced Paw Edema in Mice
}

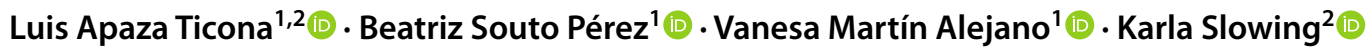

Received: 29 March 2021 / Accepted: 24 June 2021

(c) The Authors 2021

\begin{abstract}
Two glycosylated flavonoids, the quercetin-3- $O-\beta$-D-xylofuranosyl- $(1 \rightarrow 2)-\alpha-\mathrm{L}-$ rhamnopyranoside and myricetin-3- $O$ - $\beta$-Dxylofuranosyl-( $1 \rightarrow 2)-\alpha-\mathrm{L}-$ rhamnopyranoside, were isolated from the $\mathrm{CH}_{2} \mathrm{Cl}_{2} / \mathrm{MeOH}$ fraction of Syzygium jambos (L.) Alston, Myrtaceae. The structures of these compounds were elucidated by spectroscopic means. The cytotoxicity of the compounds was evaluated against the RAW 264.7 cell lines by the lactate dehydrogenase assay. All analyzed compounds were less cytotoxic than the positive control (actinomycin $\mathrm{D}, \mathrm{CC}_{50}=0.008 \mu \mathrm{M}$ ). The anti-inflammatory and anti-arthritic activities were evaluated by measuring inflammatory parameters in murine models. The two glycosylated flavonoids inhibited the production of tumor necrosis factor- $\alpha$ in RAW 264.7 cell line with $\mathrm{IC}_{50}$ of 1.68 and $1.11 \mu \mathrm{M}$, respectively. In addition, all flavonoids decreased the levels of tumor necrosis factor- $\alpha$, C-reactive protein, and fibrinogen at a dose of $5 \mathrm{mg} / \mathrm{kg}$ in murine models.
\end{abstract}

Keywords Rose apple $\cdot$ Polyphenols $\cdot$ TNF- $\alpha \cdot$ NF- $\kappa B$ - Inflammation

\section{Introduction}

Inflammation is a response of self-protection from the body against the harmful agents that are involved in damaging the cells, tissues, and organs (Kuprash and Nedospasov 2016). Inflammation is providing assistance to the body to get rid of harmful agents, and injured tissue components, so that the body can begin to heal (Kuprash and Nedospasov 2016). During an inflammatory reaction swelling, loss of function and pain are the dominating signs of inflammation because of the release of various inflammatory cytokines such as tumor necrosis factor- $\alpha$ (TNF- $\alpha$ ) (Zelová and Hošek 2013). However, prolonged existence of uncontrolled inflammation gives rise to the development of various diseases such as rheumatoid arthritis (RA) (Harth and Nielson 2019). TNF- $\alpha$ is abundantly present in RA patients' serum and the

Luis Apaza Ticona

luis.apaza@uam.es

1 Department of Organic Chemistry, Faculty of Sciences, Autonomous University of Madrid, Calle Francisco Tomás y Valiente, 7, Madrid 28049, Spain

2 Department of Pharmacology, Pharmacognosy and Botany, Faculty of Pharmacy, Complutense University of Madrid, Plaza de Ramón y Cajal, s / n, Madrid 28040, Spain arthritic synovium as a primary and major cytokine disturbing the controlled balance between pro- and anti-inflammatory cytokines (Zelová and Hošek 2013). Indeed, TNF- $\alpha$ is known to be a potent inducer of other pro-inflammatory mediators including interleukin $1 \beta$ (IL-1 $\beta$ ), chemokines, and proteases (Farzaei et al. 2019).

Conventionally, the treatment of RA is based upon diseasemodifying anti-rheumatic drugs like methotrexate, which slow down joint damage and reduce joint swelling and pain (Friedman and Cronstein 2019). However, treatment of RA has been revolutionized by the discovery of the role of certain cytokines, in particular TNF- $\alpha$, in the pathogenesis of the disease (Udalova et al. 2016). Since the first developments of TNF- $\alpha$ inhibitors in RA in the 1980s, drugs as adalimumab, certolizumab pegol, etanercept, golimumab, and infliximab have shown improving clinical, functional, and radiological outcomes in patients with RA disease (Abbasi et al. 2019). However, all anti-TNF- $\alpha$ agents have produced common adverse effects (occurring in more than $10 \%$ of patients) that include headaches, injection site reaction with the subcutaneous route and infusion reaction with the intravenous route of administration, rashes, anemia, transaminitis (usually mild), upper respiratory tract infections, sinusitis, cough, pharyngitis, diarrhea, nausea, and abdominal pain (Puxeddu et al. 2016). Therefore, it has become important and essential to develop safer and more cost-effective TNF- $\alpha$ 
inhibitors. In nature, many natural compounds belonging to various classes have been found to reduce TNF- $\alpha$ levels (Ye et al. 2016). These natural compounds have been found to interfere with various pro-inflammatory mediators, such as nuclear factor kappa-light-chain-enhancer of activated B cells (NF- $\mathrm{B}$ ) and other signaling molecules, involved in TNF- $\alpha$ expression and, thus, they could provide an alternative means of treating RA, modulating the production, rather than the activity of TNF- $\alpha$ (Doss et al. 2016).

The genus Syzygium is one of 131 genera (about 1200 species) belonging to the family Myrtaceae which are native to the tropics, particularly, in tropical America and Asia (de Paulo Farias et al. 2020). Many species of this genus are used popularly to treat digestive tract disorders, dental pain, and arthritis (Chua et al. 2019). Syzygium jambos (L.) Alston commonly known as "rose apple" is a medicinal plant widely used in Guatemala, but is also found in Bangladesh, Nepal, Malaysia, and sub-Saharan Africa (Hossain et al. 2016). The decoction of the fruit and leaves are traditionally used for its antipyretic and anti-inflammatory properties, such as gastrointestinal disorders, rheumatism, and tooth ailments and to relieve sore eye conditions (Chua et al. 2019).

The pharmacological value of $S$. jambos has been documented (Haque et al. 2015). Generally, leaf aqueous and alcoholic extracts have shown a promising anti-inflammatory activity (Hossain et al. 2016). Chemical investigation of the active extracts revealed several secondary metabolites. For instance, flavonoids, tannins, and triterpenoids (Sobeh et al. 2018). Slowing et al. (1994) suggested that myricetin<smiles>[R][R]([R])=O</smiles>

3-O-xylosyl- $(1 \rightarrow 2)$ rhamnoside and quercetin were the main compounds responsible for the anti-inflammatory action of this medicinal plant. Accordingly, the present work was carried out to evaluate the anti-inflammatory and anti-arthritic activities of the aqueous extract of $S$. jambos and two of its isolated glycosylated flavonoids ( $\mathbf{1}$ and $\mathbf{2}$ ) in the edematogenic agent-induced mice paw inflammation.

\section{Materials and Methods}

\section{General Experimental Procedures}

Thin-layer chromatography was performed using Merck silica gel 60-F254 plates, which were visualized by UV absorbance (254 nm). Developed plates were stained with phosphomolybdic acid $\left(\mathrm{H}_{3} \mathrm{PMo}_{12} \mathrm{O}_{40}\right)$ solution in ethanol for detection through heating. Open column chromatography was performed with silica gel (20-45 and 40-63 $\mu \mathrm{m})$. Nuclear magnetic resonance (NMR) experiments were performed on a Bruker Analytische Messtechnik GmbH spectrometer operating at $250 \mathrm{MHz}\left({ }^{1} \mathrm{H}\right)$ or $75 \mathrm{MHz}\left({ }^{13} \mathrm{C}\right)$ and Bruker BioSpin $\mathrm{GmbH}$ operating at $300 \mathrm{MHz}\left({ }^{1} \mathrm{H}\right)$ or $76 \mathrm{MHz}\left({ }^{13} \mathrm{C}\right)$. Spectra were calibrated by assignment of the residual solvent peak to $\delta_{\mathrm{H}} 7.26 \mathrm{ppm}$ and $\delta_{\mathrm{C}} 77.16 \mathrm{ppm}$ for $\mathrm{CDCl}_{3}, \delta_{\mathrm{H}} 3.31 \mathrm{ppm}$ and $\delta_{\mathrm{C}} 49 \mathrm{ppm}$ for MeOD, and $\delta_{\mathrm{H}}$ $4.79 \mathrm{ppm}$ for $\mathrm{D}_{2} \mathrm{O}$.

\section{Plant Material}

The leaves of Syzygium jambos (L.) Alston, Myrtaceae, were collected at the Chimaltenango Municipality, Guatemala $\left(14^{\circ} 40^{\prime} 21.4^{\prime \prime} \mathrm{N}, 90^{\circ} 47^{\prime} 53.7^{\prime \prime} \mathrm{W}\right)$ at an altitude of $1800 \mathrm{~m}$. The botanical identification was confirmed by Dr. Antonio Galán, the Botany Department Herbarium of the Faculty of Pharmacy (Universidad Complutense), where a sample was deposited (herbarium number 136091).

\section{Isolation}

The air-dried leaves (100 g) were extracted by decoction (30 min at boiling point) with distilled water (900 g). The resulting aqueous extract was frozen in glass containers at a temperature of $-38^{\circ} \mathrm{C}$ and then lyophilized (Freeze dryer, Christ alpha $1 \mathrm{e} 2 \mathrm{LD}$ plus, Germany) at $-50{ }^{\circ} \mathrm{C}$. Subsequently, the residue $(80 \mathrm{~g})$ was further extracted with $n$-heptane $\left(n-\mathrm{C}_{7} \mathrm{H}_{16}\right), \mathrm{CH}_{2} \mathrm{Cl}_{2} / \mathrm{MeOH}(1: 1)$, and $\mathrm{H}_{2} \mathrm{O}$. As a result, three fractions were obtained: $5 \mathrm{~g} n-\mathrm{C}_{7} \mathrm{H}_{16}$ fraction, $35 \mathrm{~g} \mathrm{CH}_{2} \mathrm{Cl}_{2} / \mathrm{MeOH}$ fraction, and $30 \mathrm{~g}$ aqueous fraction. Each fraction was evaluated for its cytotoxicity and antiinflammatory activities.

The $\mathrm{CH}_{2} \mathrm{Cl}_{2} / \mathrm{MeOH}$ fraction (30 g) was the most active and further fractionated using a chromatographic column (silica gel; 40-63 $\mu \mathrm{m}$ ) using a step gradient of $n-\mathrm{C}_{7} \mathrm{H}_{16}$ l EtOAc $(7: 1 \rightarrow 3: 1)$ to produce ten fractions $(\mathrm{I}-\mathrm{X})$. Fractions VIII (3.7 g) and IX (2.8 g) were observed to be the most active fractions (anti-inflammatory activity). The chromatographic profile analysis of these fractions showed that 
they were similar, so they were pooled. A second a chromatographic column (silica gel; 20-45 $\mu \mathrm{m}$ ) was performed using a step gradient $n-\mathrm{C}_{7} \mathrm{H}_{16} /$ EtOAc $(3: 1 \rightarrow 0: 3)$. Five sub-fractions (1-5) were obtained and all of them showed anti-inflammatory activity, but sub-fractions $4(1 \mathrm{~g})$ and 5 $(0.75 \mathrm{~g})$ were the most active. The chromatographic profile of sub-fractions 4 and 5 showed that they were pure (>99\%). They were identified as being quercetin-3-O- $\beta$-Dxylofuranosyl- $(1 \rightarrow 2)-\alpha$-L-rhamnopyranoside $(\mathbf{1} ; \mathrm{R} f 0.43$, EtOAc/Butanone/ $\left./ \mathrm{HCO}_{2} \mathrm{H} / \mathrm{H}_{2} \mathrm{O}, 5: 3: 1: 1\right)$ and myricetin-3O- $\beta$-D-xylofuranosyl- $(1 \rightarrow 2)$ - $\alpha$-L-rhamnopyranoside $(2 ; \mathrm{R} f$ 0.36 , EtOAc/Butanone $/ \mathrm{HCO}_{2} \mathrm{H} / \mathrm{H}_{2} \mathrm{O}, 5: 3: 1: 1$ ). The percentage obtained of each isolated compound from the $\mathrm{CH}_{2} \mathrm{Cl}_{2}$ / $\mathrm{MeOH}$ fraction was $0.7 \%(\mathbf{1})$ and $0.5 \%(2)$.

Quercetin-3-O- $\beta$-D-xylofuranosyl-( $(\rightarrow 2)$ - $\alpha$-Lrhamnopyranoside (1): light yellow solid powder; ${ }^{1} \mathrm{H}$ and ${ }^{13} \mathrm{C}$ NMR data (Fig. 9S-14S and Table 1S). The ${ }^{1} \mathrm{H}$ and ${ }^{13} \mathrm{C}$ NMR spectroscopic data were identical with those previously described (Slowing et al. 1994).

Myricetin-3-O- $\beta$-D-xylofuranosyl- $(1 \rightarrow 2)$ - $\alpha$-Lrhamnopyranoside (2): intense yellow solid powder; ${ }^{1} \mathrm{H}$ and ${ }^{13} \mathrm{C}$ NMR data (Fig. $15 \mathrm{~S}-18 \mathrm{~S}$ and Table $1 \mathrm{~S}$ ). The ${ }^{1} \mathrm{H}$ and ${ }^{13} \mathrm{C}$ NMR spectroscopic data were identical with those previously described (Slowing et al. 1994).

\section{Cytotoxicity Assay}

For this assay, the protocol developed by Apaza Ticona et al. (2021) was used. RAW 264.7 cell proliferation was determinate using the commercial Lactate Dehydrogenase kit (LDH, Innoprot Company, Bizkaia, Spain). Cells were sub-cultured in 96 well culture plates at a density of $1 \geq 10^{4}$ cells/well in $100 \mu$ l of DMEM medium and incubated for $24 \mathrm{~h}$ at $37^{\circ} \mathrm{C}$. After 24-h incubation, the old medium was removed and the cells were filled with $100 \mu \mathrm{l}$ of fresh medium treated with the samples to be analyzed.

Stock solutions of the samples were prepared by dissolving them in DMSO at a concentration of $20 \mathrm{mg} / \mathrm{ml}$ for the extract and the fractions, and $10 \mathrm{mM}$ for the compounds. Subsequently, from the stock solutions, a series of dilutions were performed until a final DMSO concentration of $0.1 \%$ was obtained in each of the wells of the plate for each of the tested concentrations $(100,50,25,12.5,6.3,3.1,1.6,0.8$, 0.4 , and $0.2 \mu \mathrm{g} / \mathrm{ml}$ or $\mu \mathrm{M})$. Actinomycin D ( $\geq 95 \%$ SigmaAldrich; CAS Number 50-76-0) was used as a positive control at a concentration of $0.01 \mu \mathrm{g} / \mathrm{ml}$ for the extract and fractions, equivalent to $0.008 \mu \mathrm{M}$ for the compounds. The treated plates were incubated in a humidified incubator at $37{ }^{\circ} \mathrm{C}$ under a $5 \% \mathrm{CO}_{2}$ atmosphere for $6 \mathrm{~h}$. After the treatment with the samples, $100 \mu$ l of culture medium supernatants was collected and incubated in the reaction mixture of the LDH kit. After $30 \mathrm{~min}$, the reaction was stopped by the addition of $1 \mathrm{~N} \mathrm{HCl}$, and the absorbance at a wavelength of $490 \mathrm{~nm}$ was measured using a spectrophotometric ELISA (enzyme-linked immunosorbent assay plate reader, SpectraMax ${ }^{\circledR}$ i3, Molecular Devices, CA, USA).

\section{Inhibition of TNF-a Production}

The protocol developed by Tena Pérez et al. (2020) was used for this assay. RAW 264.7 cell $\left(1 \times 10^{4}\right.$ cells/well $)$ were seeded on a 96-well culture plates and incubated for $6 \mathrm{~h}$. The cells were then treated with the extracts, fractions, and compounds at the same concentrations used in the viability assays for $2 \mathrm{~h}$, before stimulation with $0.1 \mu \mathrm{g} / \mathrm{ml}$ of the LPS (lipopolysaccharide) with or without samples for $6 \mathrm{~h}$. Supernatants were then collected, and the protein expression levels of TNF- $\alpha$ were measured by using an ELISA kit, according to the manufacturer's instructions (Diaclone Company, Besancon, France). Absorbance was read at $450 \mathrm{~nm}$ on a spectrophotometric ELISA plate reader (Anthos 2020, version 2.0.5, Biochrom Ltd., UK). The percentage of TNF- $\alpha$ inhibition was calculated from the ratio between the observed TNF- $\alpha$ amount secreted by treated cells ( $\mu \mathrm{g} /$ $\mathrm{ml}$ or $\mu \mathrm{M})$ and the baseline secretion of TNF- $\alpha(\mathrm{pg} / \mathrm{ml})$. C87 (3-phenyl-1-(4-phenyl-2-thiazolyl)- $1 H$-pyrazole-4,5-dione4-[2-(4-chloro-3-nitrophenyl)-hydrazone]; $\geq 98 \%$ SigmaAldrich; 332,420-90-3) was used as positive control at a concentration of $0.055 \mu \mathrm{g} / \mathrm{ml}$ for the extract and fractions, equivalent to $0.11 \mu \mathrm{M}$ for the compounds. Results were normalized to the DMSO solvent control (1\%).

\section{Anti-inflammatory Activity}

\section{Measurement of Paw Edema}

The anti-inflammatory activity of the aqueous extract, fractions, and isolated compounds was evaluated by the method of carrageenan-induced inflammation in the anterior paw of the mice as described by Apaza Ticona et al. (2021). Seven groups (5 mice for group) were selected for this study. Group 1 served as negative control and received normal saline solution at a dose of $5 \mathrm{ml} / \mathrm{kg}$ (p.o.), group 2 received $\lambda$-carrageenan (CARR, Sigma-Aldrich; CAS Number $9064-57-7)(300 \mu \mathrm{g} / \mathrm{paw}, 50 \mu \mathrm{l}$ of $0.9 \%$ saline solution), and group 3 received indomethacin (IND, 98.5-100.5\% Sigma-Aldrich; CAS Number 53-86-1) $5 \mathrm{mg} / \mathrm{kg}$ (p.o.) and served as the positive control; while for groups 4-7, they were treated with aqueous extracts $(5 \mathrm{mg} / \mathrm{kg}$, p.o. $)$, fractions $(5 \mathrm{mg} / \mathrm{kg}$, p.o.), and compounds ( $5 \mathrm{mg} / \mathrm{kg}$, p.o.). The dose of $5 \mathrm{mg} / \mathrm{kg}$ (p.o.) was selected for the treatments of extracts, fractions, and compounds based on the protocol of Apaza Ticona et al. (2021) to compare the anti-inflammatory effect with the positive control. After $30 \mathrm{~min}$ of the intraperitoneal treatment of the animals of groups 3-7 with IND and the samples (extract, fractions, and compounds), the inflammation was induced by the injection of $50 \mu \mathrm{l}$ of CARR solution 
(type IV Sigma Chemical Company, USA) into the right hind paw of each mouse. The thickness of the paw edema was measured immediately after CARR injection and during the $6 \mathrm{~h}$ following the induction of the edema at an interval of $1 \mathrm{~h}$ after the administration of the edematogenic agent using a plethysmometer (model 520, IITC Life Science, Woodland Hills, CA). All the assessments were performed by the same investigator in order to reduce any potential inter-operator differences. The size of the edema was calculated as follows:

$\mathrm{E}_{\text {edema }}=\mathrm{X}_{\mathrm{t}}-\mathrm{X}_{0}$

$X_{t}$ size of the paw edema after edematogenic agent (CARR) injection at " $t$ ".

$\mathrm{X}_{0}$ size of the paw edema before edematogenic agent (CARR) injection.

The anti-inflammatory activity was calculated as a percentage of inhibition of edema by the extract in treated animals under test in comparison with the CARR control group.

$\%$ Inhibition $=[((\mathrm{X}-\mathrm{Y}) / \mathrm{X})] * 100$

\section{$\mathrm{X}$ Increase in paw edema of the CARR group}

$\mathrm{Y}$ Increase in paw edema of the treated group

The animals were sacrificed after $6 \mathrm{~h}$. The CARR-induced edema feet were dissected and stored at $-70{ }^{\circ} \mathrm{C}$. Blood samples were taken from anesthetized mice $6 \mathrm{~h}$ after the CARR administration and kept at $-70{ }^{\circ} \mathrm{C}$. According to the type of assay, samples were taken: in citrate tubes to be centrifuged for $15 \mathrm{~min}$ at 1792 relative centrifugal force (RCF) obtaining a plasma isolate to analyze TNF- $\alpha$, in heparin tubes to be centrifuged for $15 \mathrm{~min}$ at $1792 \mathrm{RFC}$ obtaining a plasma isolate to analyze C-reactive protein (CRP), and in citrate tubes to be centrifuged for 15 min at 1792 RFC obtaining a plasma isolate to analyze fibrinogen.

\section{Measurement of Inflammatory Parameters}

The serum levels of TNF- $\alpha$ were determined using an ELISA kit, using the manufacturer's instructions (Diaclone Company, Besancon, France). Absorbance was read at $450 \mathrm{~nm}$ on a spectrophotometric ELISA plate reader (Anthos 2020, version 2.0.5, Biochrom Ltd., UK). TNF- $\alpha$ was determined from a standard curve. The CRP dosage was determined by an automatic analyzer COBAS INTEGRA@ 400 plus analyzer $\mathrm{C}$-reactive. The results were automatically calculated in terms of concentration. The CRP level is expressed in milligrams per liter of serum. The plasma fibrinogen assay was determined according the methodology described by Apaza Ticona et al.
(2021) on the STA line machine. The plasma samples to be tested were loaded into the STA line apparatus, where they were diluted by Owren-Koller buffer $(\mathrm{pH}=7.35)$ (the dilutions were carried out automatically by the apparatus). Then, the reagent STA-Fibrinogen was added. The level of fibrinogens in the tested samples is expressed in grams per liter of plasma.

\section{Anti-arthritic Activity}

\section{Measurement of Paw Edema}

Experimental arthritis was induced in mice according to the method used by Apaza Ticona et al. (2021). Eight groups (five mice for group) were selected for this study. Group 1 served as negative control and received normal saline solution at a dose of $5 \mathrm{ml} / \mathrm{kg}$ (p.o.), group 2 received $0.05 \mathrm{ml}$ (s.c.) of Freund's Complete Adjuvant (CFA, Sigma-Aldrich; MDL number MFCD00131105) (CFA, 1\% suspension in olive oil; Difco), and group 3 received IND (5 mg/kg, p.o.) in $1 \%$ carboxymethylcellulose as a positive control. Mice in groups 4-7 were treated with the aqueous extract $(5 \mathrm{mg} /$ $\mathrm{kg}$, p.o.), fractions ( $5 \mathrm{mg} / \mathrm{kg}$, p.o.), and isolated compounds $(5 \mathrm{mg} / \mathrm{kg}$, p.o.) $24 \mathrm{~h}$ before of the injection of CFA and, then, with a daily treatment until 14 days after CFA challenge. The edema and inflammatory parameters were measured with the same methods described above.

\section{Statistical Analysis}

$\mathrm{CC}_{50}$ (cytotoxic concentration $50 \%$ ) and $\mathrm{IC}_{50}$ (inhibitory concentration 50\%) values were determined by non-linear regression. All the experiments were performed in triplicate. For the results of the inflammatory assays in plantar edema, the data are presented as means \pm S.E.M., except for the $\mathrm{ID}_{50}$ values, which are reported as geometric means accompanied by their respective $95 \%$ confidence limits. Two-way ANOVA statistical analysis (Š́́dák's multiple comparisons test $* * p<0.01$ and $* * * p<0.001)$ was performed to evaluate the significant differences among values. All the analyses were performed using GraphPad Prism, version 9.0.0. Software (CA, USA).

\section{Results and Discussions}

RAW 264.7 cells were selected as a useful tool to assay the in vitro viability (LDH) and anti-inflammatory (inhibition of TNF- $\alpha$ production) of the extract, fractions, and isolated compounds from $S$. jambos. The objective of the present investigation was to provide preliminary evidences for the ethnopharmacological use of this species as an antipyretic and anti-inflammatory cure (rheumatism) (Chua et al. 2019). 


\section{Cytotoxic Effects}

First, the viability of the RAW 264.7 cells was evaluated after $12 \mathrm{~h}$ of treatment with the prepared extract or the fractions. The aqueous extract did not show a statistically significant cytotoxic effect $\left(\mathrm{CC}_{50}=98.91 \mu \mathrm{g} / \mathrm{ml}, p=0.086\right)$ when compared to the positive control (ACT, $\mathrm{CC}_{50}=13.04 \mu \mathrm{g}$ / $\mathrm{ml}$ ) in the RAW 264.7 cell line (Fig. 1S). Regarding the cytotoxicity of the assayed fractions, the results showed that the $n-\mathrm{C}_{7} \mathrm{H}_{16}\left(\mathrm{CC}_{50}=90.91 \mu \mathrm{g} / \mathrm{ml}\right), \mathrm{CH}_{2} \mathrm{Cl}_{2} / \mathrm{MeOH}$ $\left(\mathrm{CC}_{50}=96.25 \mu \mathrm{g} / \mathrm{ml}\right)$, and aqueous $\left(\mathrm{CC}_{50}=98.01 \mu \mathrm{g} /\right.$ $\mathrm{ml}$ ) fractions did not show a relevant cytotoxicity $(p=0.080)$ when compared to the positive control (ACT, $\left.\mathrm{CC}_{50}=13.04 \mu \mathrm{g} / \mathrm{ml}\right)\left({ }^{\mathrm{ns}} p=0.011\right)$ (Fig. 1S). However, the $n-\mathrm{C}_{7} \mathrm{H}_{16}$ fraction decreased the viability of all cell lines when compared to the negative control (untreated cells) $\left(\mathrm{CC}_{50}=99.51 \mu \mathrm{g} / \mathrm{ml}, * * * p<0.001\right)$ (Fig. 1S). Previously, Rocchetti et al. (2019) reported the cytotoxicity of a series of methanol extracts of different Syzygium species, mentioning that the methanolic extract of $S$. jambos did not present cytotoxicity at a concentration of $100 \mu \mathrm{g} / \mathrm{ml}$ on the MCF-7 cell line. In our case, $\mathrm{CH}_{2} \mathrm{Cl}_{2} / \mathrm{MeOH}$ fraction could be compared with this methanol extract of $S$. jambos, showing no high cytotoxicity, due to the chemical composition of the extract, being mainly phenolic compounds.

\section{Inhibition of TNF-a Production}

The aqueous fraction showed an inhibition of TNF- $\alpha$ production at an $\mathrm{IC}_{50}=59.36 \mu \mathrm{g} / \mathrm{ml}(p=0.081)$ when compared to the positive control $\left(\mathrm{C} 87, \mathrm{IC}_{50}=0.052 \mu \mathrm{g} / \mathrm{ml}\right)$ in the RAW 264.7 cell line (Fig. 2S). The results showed that the $\mathrm{CH}_{2} \mathrm{Cl}_{2} / \mathrm{MeOH}$ fraction $\left(\mathrm{IC}_{50}=45.15 \mu \mathrm{g} / \mathrm{ml}\right)$ presented a higher inhibitory activity of TNF- $\alpha$ than the $n-\mathrm{C}_{7} \mathrm{H}_{16}$ fraction $\left(\mathrm{IC}_{50}=79.55 \mu \mathrm{g} / \mathrm{ml}\right)$ and the aqueous fraction $\left(\mathrm{IC}_{50}=87.37 \mu \mathrm{g} / \mathrm{ml}\right)$ in the RAW 264.7 cell line (Fig. $2 \mathrm{~S}$ ). These results show that both fractions have anti-inflammatory activity by inhibiting the cytokine TNF- $\alpha$, which is one of the main pro-inflammatory cytokines involved in the pathogenesis of chronic inflammatory diseases. It also triggers the cellular release of other cytokines, chemokines, or inflammatory mediators (Zelová and Hošek 2013).

The analysis of the inhibitory activity of TNF- $\alpha$ obtained with the different treatments indicated that the differences in the $\mathrm{IC}_{50}$ values are due to their chemical composition. For the aqueous fraction, and according to its proton spectrum (Fig. 3S), it presents signals corresponding to polyphenolic compounds (7.5-6.5 ppm) (Apaza Ticona et al. 2021), polysaccharides (5.5-3.5 ppm) (Merkx et al. 2018), fatty acids (2.5-1.0 ppm) (Castejón et al. 2016), being the polysaccharides are in higher proportion. In the case of $n-\mathrm{C}_{7} \mathrm{H}_{16}$ fraction, the presence of fatty acids $(2.5-1 \mathrm{ppm})$ in the proton spectrum (Fig. 4S) is observed in a higher proportion than the presence of other types of compounds (polyphenols and polysaccharides found in a lower proportion, almost nonexistent); while for the $\mathrm{CH}_{2} \mathrm{Cl}_{2} / \mathrm{MeOH}$ fraction, its proton spectrum (Fig. 5S) indicates the presence of polyphenolic compounds (7.5-6.5 ppm) and fatty acids $(2.5-1 \mathrm{ppm})$, with fatty acids found in a higher proportion. Finally, in the proton spectrum of the aqueous fraction (Fig. 6S), signals from polyphenolic compounds (7.5-6.5 ppm) and polysaccharides (5.5-3.5 ppm) are observed, with polysaccharides being the ones found in the highest proportion. From these results, it can be concluded that the presence of polyphenolic compounds is relevant for the anti-inflammatory activity.

\section{Effect on the Inflammatory Parameters}

As shown in Fig. 1A, the sub-plantar injection of CARR induced an edema which thickens slowly. The edema size variation follows a polynomial function. In fact, $2 \mathrm{~h}$ after CARR injection, the size of the edema reached a maximum which indicates an acute inflammation; this effect of increasing edema (increase in inflammatory mediators) after $2 \mathrm{~h}$ of CARR injection has already been reported by other researchers (Makni et al. 2019). The treatment with the aqueous fraction $(5 \mathrm{mg} / \mathrm{kg})$ decreased significantly the paw edema circumference size (56.46\% of edema inhibition). Likewise, the mice treated with the $\mathrm{CH}_{2} \mathrm{Cl}_{2} / \mathrm{MeOH}$ fraction $(5 \mathrm{mg} / \mathrm{kg})$ showed higher anti-inflammatory activity (48.98\% of edema inhibition) compared to the aqueous fraction $(35.37 \%)$, but does not present a statistically significant difference with $n-\mathrm{C}_{7} \mathrm{H}_{16}$ fraction (46.94\%). As expected, the IND-positive control $(5 \mathrm{mg} / \mathrm{kg})$ also caused a significant inhibition of edema of $57.14 \%$.

Regarding the anti-arthritic activity, the sub-plantar injection of CFA led the paw to swell gradually for more than 14 days. The curves of edema rate versus time could be divided into two phases. In the first phase, edema rate of the injected footpad increased and reached a peak during the first 3 days. Thereafter, the swelling slowly subsided until the seventh day when the paw began to swell again and peaked in the second week (second phase); this effect of increasing edema (increase in inflammatory mediators) after 7 days of CFA injection has already been reported by other researchers (Gomes et al. 2013). The administration of the aqueous fraction $(5 \mathrm{mg} / \mathrm{kg})$ inhibited the development of joint swelling induced by CFA $(51.39 \%)$ when compared to the $5 \mathrm{mg} / \mathrm{kg}$ IND-positive control $(63.19 \%)$ on the eighth day after CFA injection (Fig. 1B). Finally, the mice treated with the $\mathrm{CH}_{2} \mathrm{Cl}_{2} / \mathrm{MeOH}$ fraction $(5 \mathrm{mg} / \mathrm{kg}$ ) showed higher anti-arthritic activity (54.86\% of edema inhibition) when compared to the $n-\mathrm{C}_{7} \mathrm{H}_{16}$ fraction $(42.36 \%)$ and the aqueous fraction $(35.42 \%)$ on the eighth day after the CFA injection. These results confirm those reported by Slowing et al. (1994), which indicate that the aqueous fraction (10\% 


\section{A Evolution of the Size of the Edema by CARR}

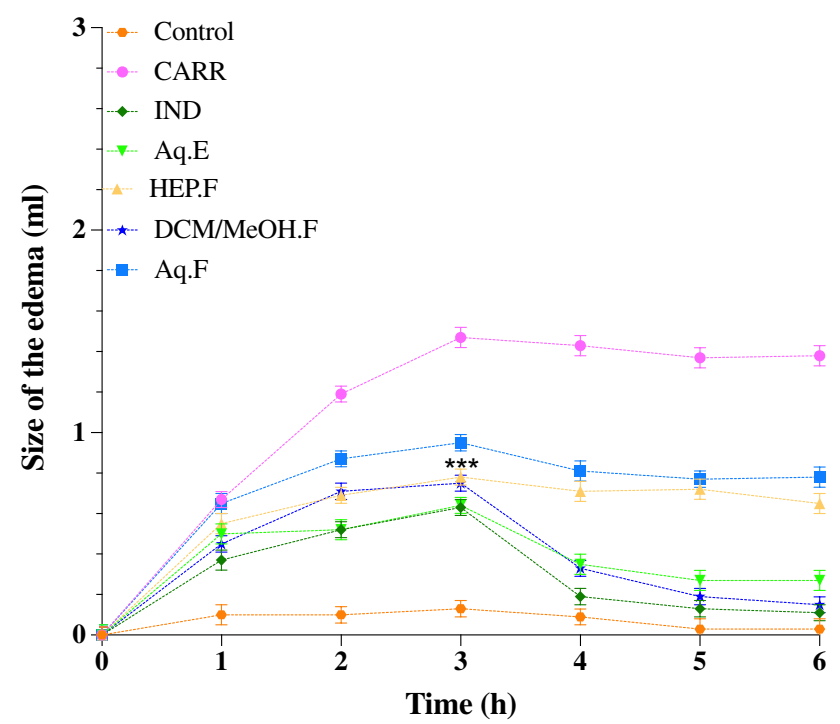

Fig. 1 Edema size evolution over time in the different groups of mice treated with the aqueous extract (Aq.E) and fractions (HEP. $\mathrm{F}=n-\mathrm{C}_{7} \mathrm{H}_{16}, \quad \mathrm{DCM} / \mathrm{MeOH} . \mathrm{F}=\mathrm{CH}_{2} \mathrm{C}_{12} / \mathrm{MeOH}$ and Aq. $\mathrm{F}=\mathrm{H}_{2} \mathrm{O}$ ) from Syzygium jambos. Control (untreated control mice). Each value represents the mean \pm SEM of results from six animals.

infusion) was very active in suppressing edema (mouse paw) in the acute phase (injection of CARR) as well as in the chronic stage (injection of CFA) of swelling.

The sub-plantar injection of CARR led to a significant increase in the TNF- $\alpha$ level in serum when reaching the fifth hour $(* * * p<0.001)$. However, the aqueous extract $(5 \mathrm{mg} /$ $\mathrm{kg}$ ) decreased the TNF- $\alpha$ level in serum when reaching the fifth hour after CARR injection $(* * * p<0.001)$ when compared to the IND group $(5 \mathrm{mg} / \mathrm{kg}$ ) (Fig. 2A). However, the sub-plantar injection of CFA led to a significantly higher increase in the TNF- $\alpha$ level in serum during the first 3 days $(* * * p<0.001)$. Yet, the aqueous fraction $(5 \mathrm{mg} / \mathrm{kg})$ decreased the TNF- $\alpha$ level in serum during the first day after CFA injection $(* * * p<0.001)$ when compared to the IND group $(5 \mathrm{mg} / \mathrm{kg})$ (Fig. 2B).

In relation to the CRP level and the fibrinogen rate, a highly significant increase was observed in the CARR group when compared to the control group $(* * * p<0.001)$. Yet, the CRP level significantly decreased $(* * * p<0.001)$ in the groups treated with the aqueous fraction $(12.21 \mathrm{mg} /$ $\mathrm{ml}), \mathrm{CH}_{2} \mathrm{Cl}_{2} / \mathrm{MeOH}$ fraction $(9.71 \mathrm{mg} / \mathrm{ml})$, and IND $(13.07 \mathrm{mg} / \mathrm{ml})$ when compared to the CARR group $(24.08 \mathrm{mg} / \mathrm{ml})$ (Fig. 3A). Also, the fibrinogen rate decreased significantly $(* * * p<0.001)$ in the groups treated with the aqueous fraction $(4.14 \mathrm{~g} / \mathrm{l}), \mathrm{CH}_{2} \mathrm{Cl}_{2} /$ $\mathrm{MeOH}$ fraction $(3.86 \mathrm{~g} / \mathrm{l})$, and IND $(3.38 \mathrm{~g} / \mathrm{l})$ when compared to the CARR group (5.14 g/l) (Fig. 3B). Finally,

\section{B Evolution of the Size of the Edema by CFA}

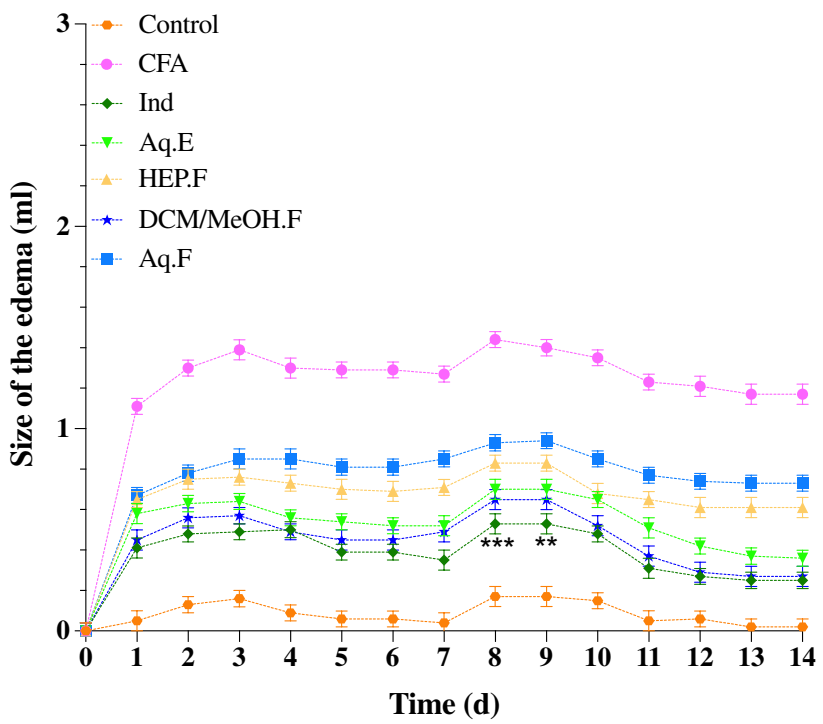

$(* * p<0.01$ and $* * * p<0.001)$ highly significant difference in comparison with inflamed mice treated with indomethacin (IND group). Two-way ANOVA followed by Šídák's multiple comparisons test for $\mathrm{CARR}=$ carrageenan (A) with a $\mathrm{F}(1.167,4.668)$ and $\mathrm{CFA}=$ Freund's Complete Adjuvant (B) with an F (1.060, 4.242)

when compared to the control group, a highly significant increase was observed in the CFA group $(* * * p<0.001)$ regarding the CRP level and the fibrinogen rate. Yet, in the groups treated with the aqueous fraction $(23 \mathrm{mg} /$ $\mathrm{ml}), \mathrm{CH}_{2} \mathrm{Cl}_{2} / \mathrm{MeOH}$ fraction $(17.78 \mathrm{mg} / \mathrm{ml})$, and IND $(27.60 \mathrm{mg} / \mathrm{ml})$, the CRP levels significantly decreased $(* * * p<0.001)$ when compared to the CFA group $(34.25 \mathrm{mg} / \mathrm{ml})$ (Fig. 4A). Additionally, the fibrinogen rate decreased significantly $(* * * p<0.001)$ in the groups treated with the aqueous fraction $(13.98 \mathrm{~g} / \mathrm{l})$, with the $\mathrm{CH}_{2} \mathrm{Cl}_{2} / \mathrm{MeOH}$ fraction (12.74 g/l) and IND (12.22 g/l) when compared to the CFA group (16.64 g/l) (Fig. 4B).

Based on the analysis of the proton spectra of aqueous extract and $\mathrm{CH}_{2} \mathrm{Cl}_{2} / \mathrm{MeOH}$ fraction (Fig. 3S and 5S), we can indicate that the signals between 7.5 and $6.5 \mathrm{ppm}$ correspond to polyphenolic compounds (flavonoids) (Apaza Ticona et al. 2021). These extracts rich in polyphenolic compounds may have anti-inflammatory activity (Bezerra et al. 2017). In our case, based on the literature and the assays that we carried out, we can indicate that its mechanism of action is inhibition of TNF- $\alpha$ by downregulation gene expression for $\mathrm{NF}-\kappa \mathrm{B}$.

\section{Effects of compounds 1 and 2}

The cytotoxic effect of compounds $\mathbf{1}$ and $\mathbf{2}$ was evaluated by the LDH assay in RAW 264.7 cells for $12 \mathrm{~h}$. The 
A

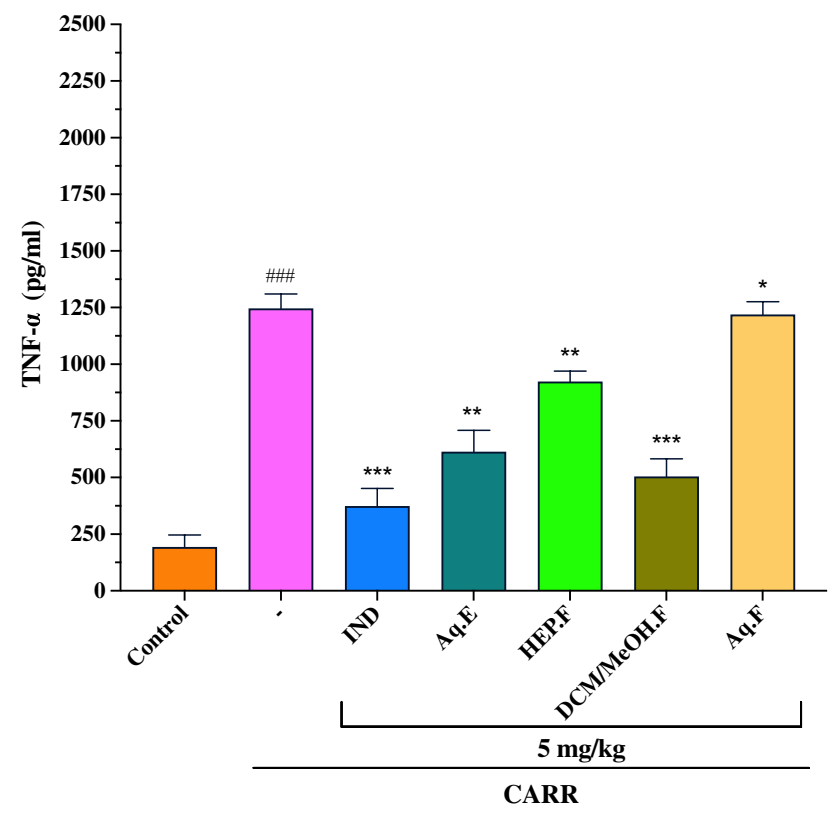

Fig. 2 The effects of the aqueous extract (Aq.E) and fractions (HEP. $\mathrm{F}=n-\mathrm{C}_{7} \mathrm{H}_{16}, \mathrm{DCM} / \mathrm{MeOH} . \mathrm{F}=\mathrm{CH}_{2} \mathrm{C}_{12} / \mathrm{MeOH}$ and $\mathrm{Aq} . \mathrm{F}=\mathrm{H}_{2} \mathrm{O}$ ) from Syzygium jambos on TNF- $\alpha$ induced by $\mathrm{CARR}=$ carrageenan (A) and CFA=Freund's Complete Adjuvant (B). Control (untreated con-

\section{B}

Effects of the Extract and Fractions on CFA-induced TNF- $\alpha$

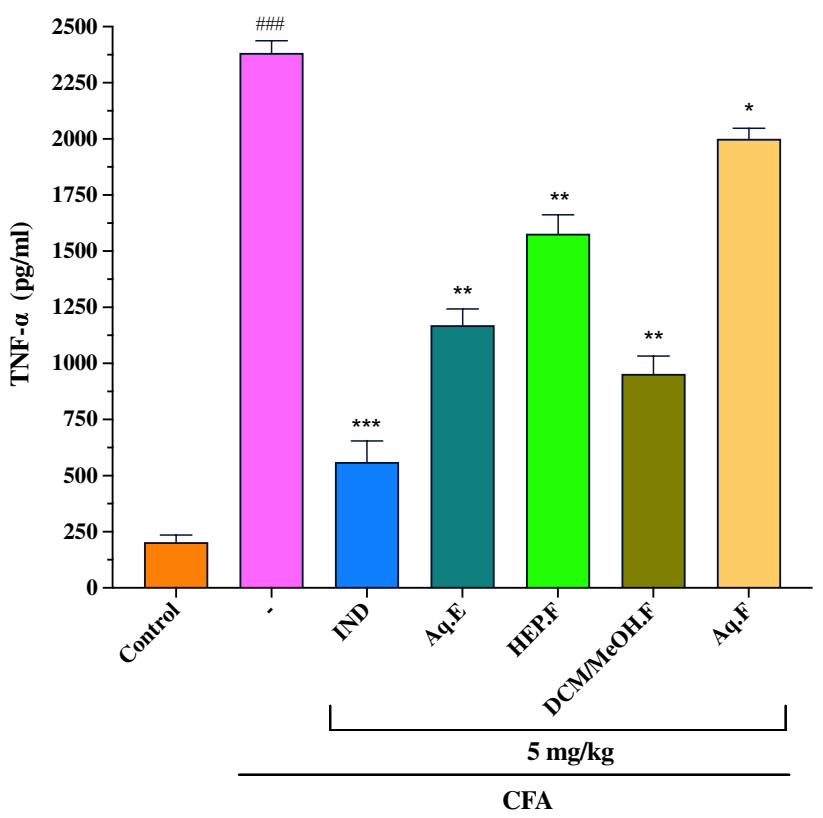

trol mice). Each value represents the mean \pm SEM of results from six animals. $(* * p<0.01$ and $* * * p<0.001)$ highly significant difference in comparison with inflamed mice treated with indomethacin (IND group) Values represent the mean $\pm \mathrm{SD}(? ?=6)$ in each group

\section{A}

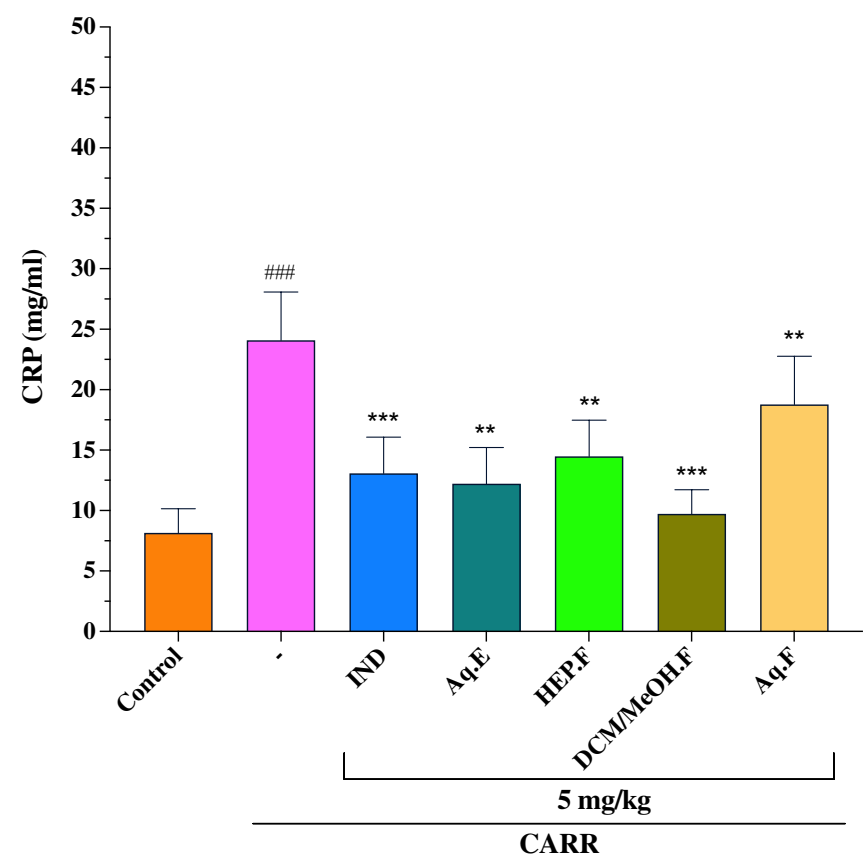

Fig. 3 Study of CRP (C-reactive protein) levels (A) and fibrinogen (B) in mice treated with the aqueous extract (Aq.E) and fractions (HEP.F $=n-\mathrm{C}_{7} \mathrm{H}_{16}, \quad \mathrm{DCM} / \mathrm{MeOH} . \mathrm{F}=\mathrm{CH}_{2} \mathrm{C}_{12} / \mathrm{MeOH}$ and Aq.F $=\mathrm{H}_{2} \mathrm{O}$ )

\section{B}

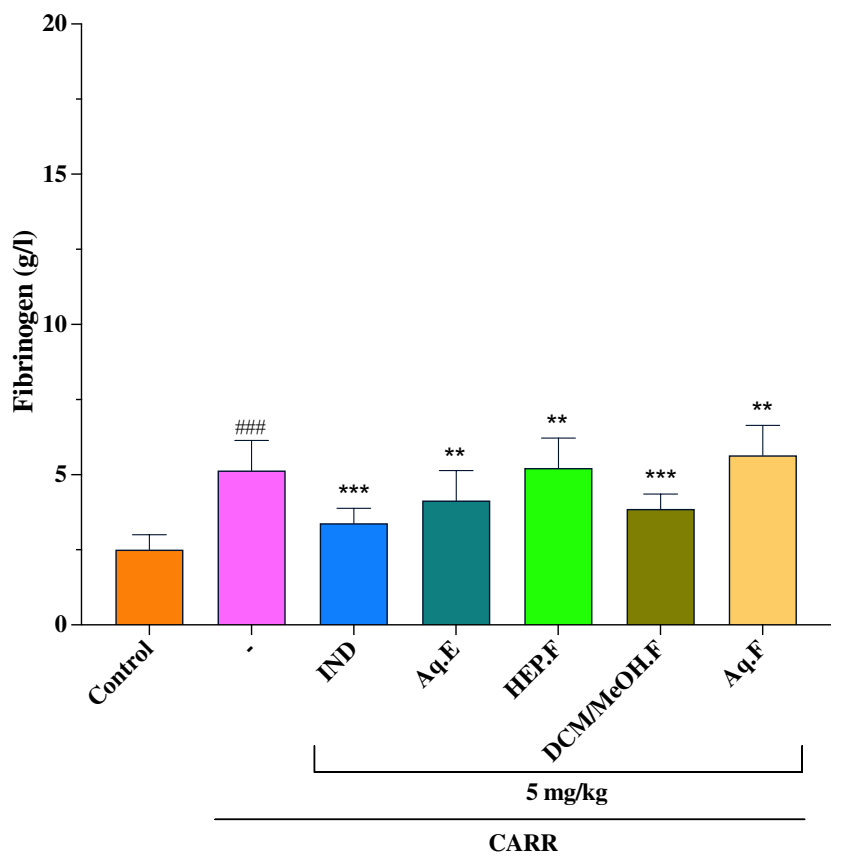

from Syzygium jambos induced by CARR (carrageenan). Values represent the mean $\pm \mathrm{SD}(? ?=6)$ in each group 


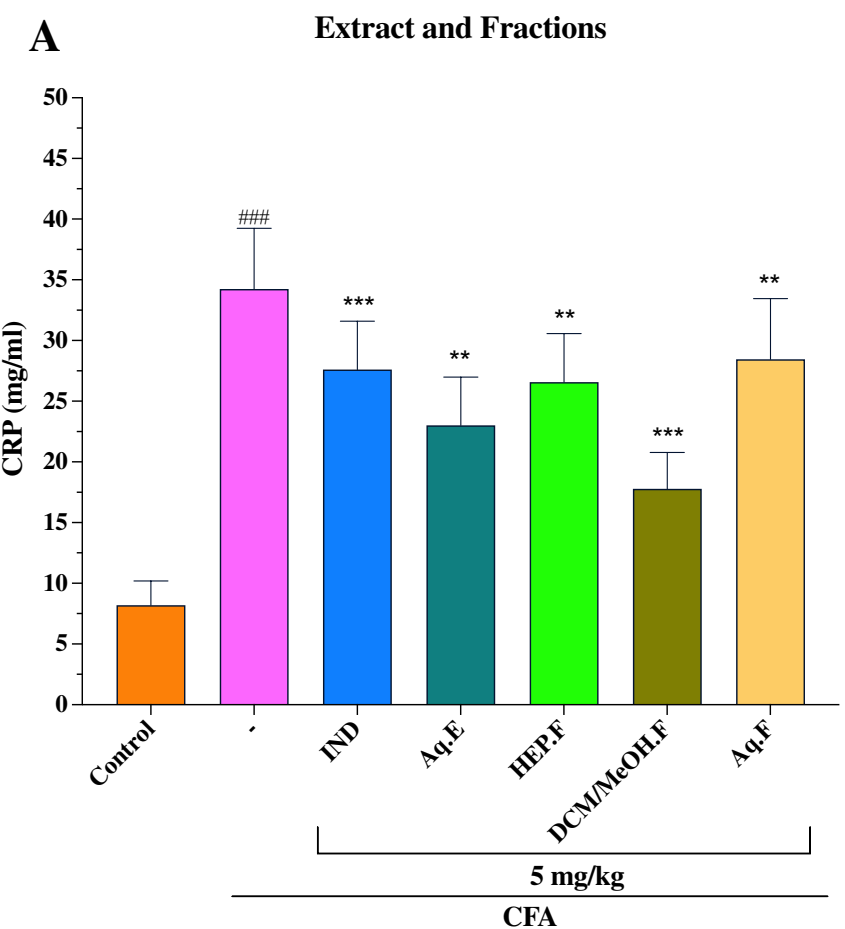

Fig. 4 Study of CRP (C-reactive protein) levels (A) and fibrinogen (B) in mice treated with the aqueous extract (Aq.E) and fractions (HEP.F $=n-\mathrm{C}_{7} \mathrm{H}_{16}, \quad \mathrm{DCM} / \mathrm{MeOH} . \mathrm{F}=\mathrm{CH}_{2} \mathrm{C}_{12} / \mathrm{MeOH}$ and Aq.F $=\mathrm{H}_{2} \mathrm{O}$ )

compounds were less cytotoxic than the ACT, used as a positive control $\left(\mathrm{CC}_{50}=0.00798 \mu \mathrm{M}\right)$ in all the tested cell lines $(* * * p<0.001)$. Compounds $\mathbf{1}\left(\mathrm{CC}_{50}=86.61 \mu \mathrm{M}\right)$ and $2\left(\mathrm{CC}_{50}=85.63 \mu \mathrm{M}\right)$ did not show a statistically significant difference $\left({ }^{\mathrm{ns}} p=0.075\right)$ when compared to the negative control (untreated cells) (Fig. 5). These compounds inhibited the production of the TNF- $\alpha$ in RAW 264.7 cell line with $\mathrm{IC}_{50}$ of $1.68(\mathbf{1})$ and $1.11 \mu \mathrm{M}(\mathbf{2})$, respectively, when compared to the positive control $\left(\mathrm{C} 87, \mathrm{IC}_{50}=0.11 \mu \mathrm{M}\right)($ Fig. $7 \mathrm{~S})$.

In Fig. 8S, the sub-plantar injection of CARR induced an edema whose size variation follows a polynomial function. The size of the edema reached its maximum expression (acute inflammation) within $2 \mathrm{~h}$ after CARR injection. In this sense, treatment with compound $1(5 \mathrm{mg} / \mathrm{kg})$ decreased the size of the circumference of the paw edema (53.59\% inhibition of edema). Likewise, mice treated with compound $2(5 \mathrm{mg} / \mathrm{kg})$ showed higher anti-inflammatory activity (61.44\% inhibition of edema) when compared to the IND-positive control $(5 \mathrm{mg} / \mathrm{kg})$ that inhibited the edema by $55.56 \%$.

Regarding the anti-arthritic activity, the sub-plantar injection of CFA led the paw to swell gradually for more than 14 days. The edema rate curves were divided into two phases as a function of time. In the first phase, edema rate of the injected footpad increased and reached a peak during the first 3 days. Thereafter, the swelling

\section{B Extract and Fractions}

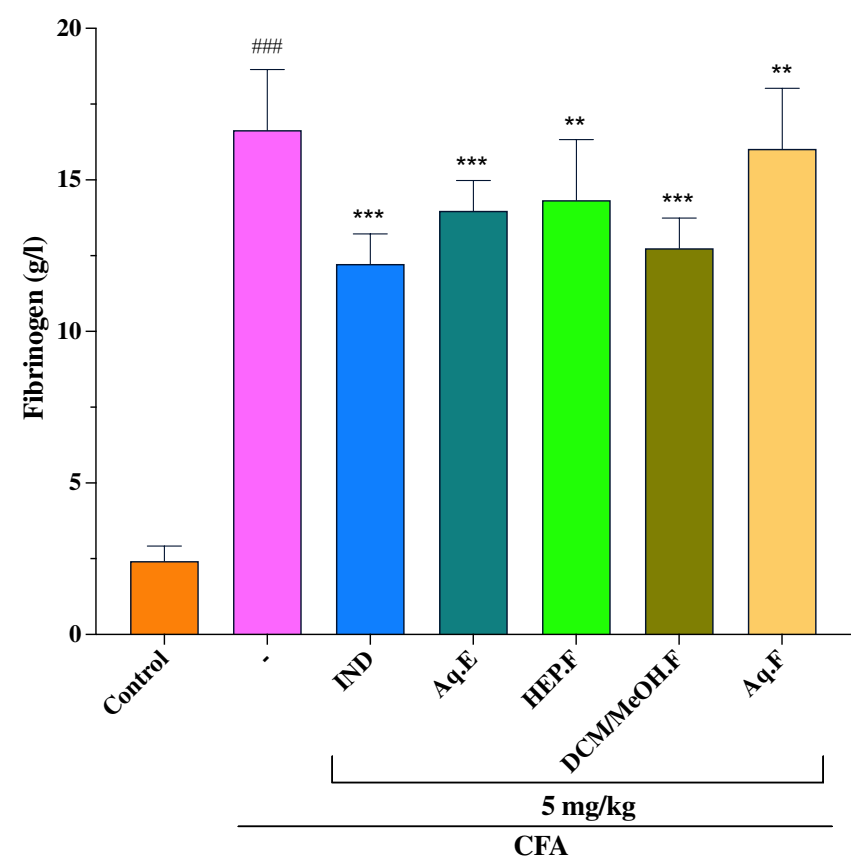

from Syzygium jambos induced by CFA (Freund's Complete Adjuvant). Values represent the mean $\pm \mathrm{SD}(? ?=6)$ in each group

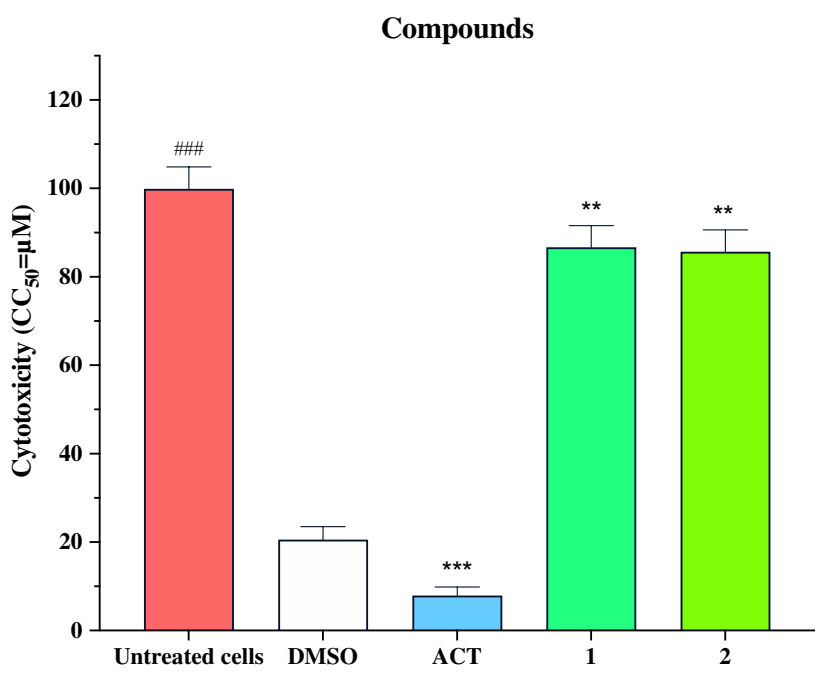

Fig. $5 \mathrm{CC}_{50 \mathrm{~s}}$ of the $\mathrm{LDH}$ (cytotoxicity) assays calculated for the quercetin-3- $O$ - $\beta$-D-xylofuranosyl- $(1 \rightarrow 2)-\alpha$-L-rhamnopyranoside $\quad(\mathbf{1})$ and myricetin-3-O- $\beta$-D-xylofuranosyl- $(1 \rightarrow 2)-\alpha$-L-rhamnopyranoside (2) compounds from Syzygium jambos. $\mathrm{CC}_{50}$ was calculated using Prism v9.0.0 (GraphPad Software) using non-linear regression, doseresponse curves. CI95\%: confidence interval 95\%/Tukey's multiple comparisons test $(* * p<0.01$ and $* * * p<0.001)$ 
slowly subsided until the seventh day when the paw began to swell again and peaked in the second week (second phase), this effect has already been reported by other researchers. The administration of compound $1(5 \mathrm{mg} / \mathrm{kg})$ significantly inhibited $(65.96 \%)$ the development of joint swelling induced by CFA when compared to the $5-\mathrm{mg} /$ $\mathrm{kg}$ IND-positive control $(58.87 \%)$ on the eighth day after CFA injection (Fig. 8S). Finally, the mice treated with compound $2(5 \mathrm{mg} / \mathrm{kg})$ showed higher anti-arthritic activity ( $66.67 \%$ of edema inhibition) on the eighth day after the CFA injection.

The compounds decreased the TNF- $\alpha$ level in the serum when reaching the fifth hour after the CARR injection $(* * * p<0.001)$. Nevertheless, compounds showed a higher decrease TNF- $\alpha$ level in serum when reaching the fifth hour after the CARR injection $(* * * p<0.001)$ when compared to IND group ( $5 \mathrm{mg} / \mathrm{kg}$ ) (Fig. 6A). Additionally, the compounds $(5 \mathrm{mg} / \mathrm{kg})$ decreased the TNF- $\alpha$ level in the serum during the first 3 days after the CFA injection $(* * * p<0.001)$. Yet, compounds decreased the TNF- $\alpha$ level in serum after the first day following the injection of CFA $(* * * p<0.001)$ when compared to the IND group $(5 \mathrm{mg} / \mathrm{kg})$ (Fig. 6B).

Statistical analysis revealed that compounds $\mathbf{1}$ and $\mathbf{2}$ and IND significantly inhibited the development of edema in the fifth hour after treatment $(* * * p<0.001)$. Both showed antiinflammatory effects on the paw of mice with edematogenic

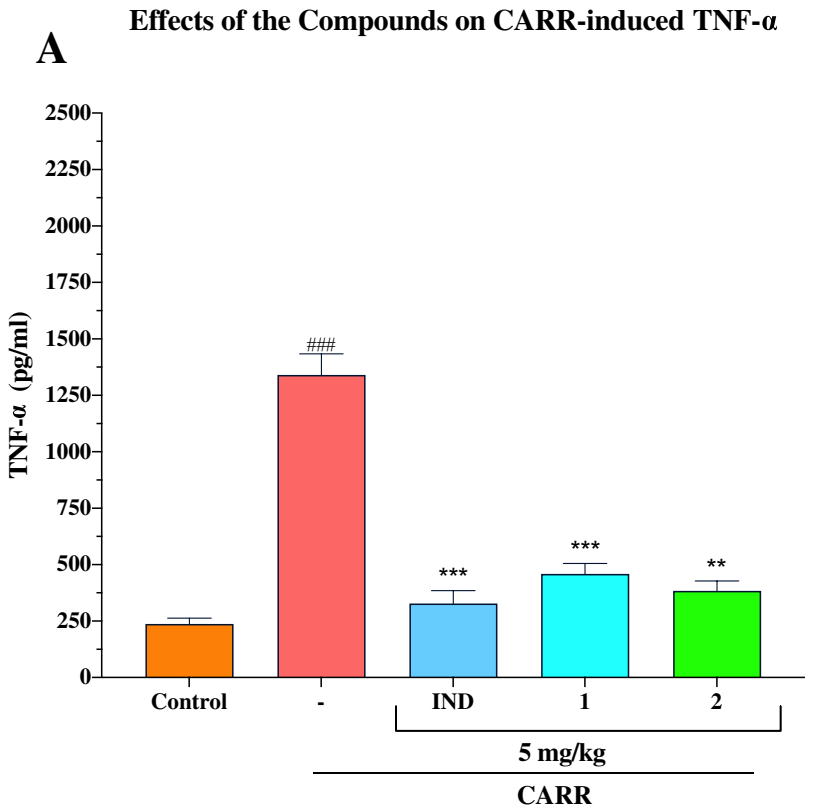

Fig. 6 The effects of the quercetin-3-O- $\beta$-Dxylofuranosyl-( $1 \rightarrow 2)-\alpha$-L-rhamnopyranoside (1) and myricetin-3$O$ - $\beta$-D-xylofuranosyl- $(1 \rightarrow 2)$ - $\alpha$-L-rhamnopyranoside $(2)$ compounds from Syzygium jambos on TNF- $\alpha$ induced by CARR $=$ carrageenan (A) and CFA=Freund's Complete Adjuvant (B). Control (untreated agent-induced edema. Likewise, compounds $\mathbf{1}$ and $\mathbf{2}$ and IND significantly $(* * * p<0.001)$ inhibited the development of edema in the first 3 days after injection of CFA in the paw of mice.

Flavonoids belong to a group of natural substances with variable phenolic structures, found in the form of aglycones, glycosides, and methylated derivatives in plants (Rha et al. 2019). Flavonoids are active redox agents and have been reported to possess in vitro and in vivo anti-inflammatory activity, through different mechanisms of action such as the inhibition of enzymes (phospholipase A2, cyclooxygenases, and lipoxygenases), suppression of inflammatory cytokines (TNF- $\alpha$, NF- $\kappa B$, IL-1 $\beta$ ), modulation of transcription factors and pathways related to inflammation, and reduced accumulation of nitric oxide (NO) or reactive oxygen species (ROS) (Farzaei et al. 2019). Catechols in flavonoids are also able to form chelates with metals and are reactive in their oxidized form (like quinones) with nucleophiles present in lateral protein chains such as cysteine and lysine. For example, several in vitro studies have revealed that the anti-inflammatory activity (inhibition of $\mathrm{NO}$ production and iNOS expression) of flavonoids is due to the double bond at carbon 2 and hydroxyl substitutions in the ring (Shen et al. 2002). Likewise, there are flavonoids that attenuate inflammation mediators such as TNF- $\alpha$ in THP-1, RAW 264.7, and J774a cells (di Gesso et al. 2015). As stated previously, studies have already shown that the inhibition of TNF- $\alpha$ by

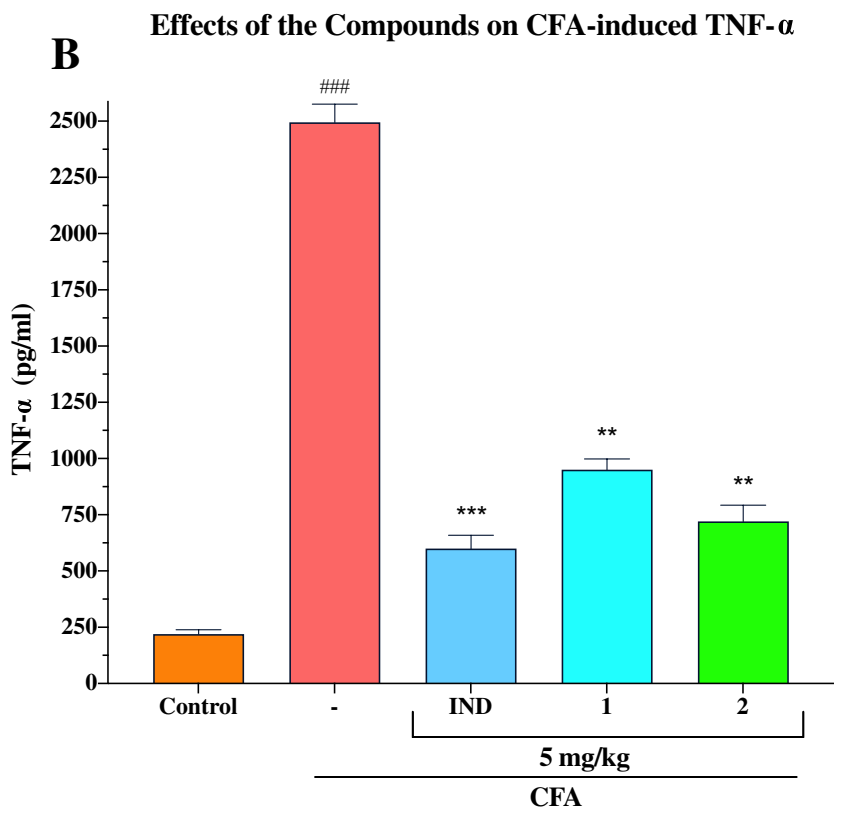

control mice). Each value represents the mean \pm SEM of results from six animals. ( $* * p<0.01$ and $* * * p<0.001)$ highly significant difference in comparison with inflamed mice treated with indomethacin (IND group). Values represent the mean $\pm \mathrm{SD}(? ?=6)$ in each group 
flavonoids is by downregulating gene expression for NF- $\mathrm{kB}$ (Ruiz et al. 2007).

Our results showed that compound $\mathbf{2}$ has a higher antiinflammatory effect (inhibition of TNF- $\alpha$, in vitro) that is not statistically significant $(p=0.0431)$. However, in in vivo assays, it is observed that both compounds showed similar values in all inflammation parameters. This difference in activity, which is not statistically significant in the in vitro assay (inhibition of TNF- $\alpha$ ), is due to the number of hydroxyls, lipophilic capacity, and its metabolism. In relation to the number of hydroxyls, although myricetin (compound $\mathbf{2}$ in aglycone form) is structurally similar to quercetin (compound $\mathbf{1}$ in aglycone form), they have different antioxidant and anti-inflammatory effects (Wang et al. 2006). Regarding lipophilic capacity, the parameter that determines the lipophilicity of a molecule is $\log \mathrm{P}$ (the partition coefficient of the molecule between an aqueous and lipophilic phase, usually water and octanol). The $\log \mathrm{P}$ is a crucial factor governing passive membrane partitioning; being that an increase in LogP enhances permeability (Tena Pérez et al. 2020). In our case, compound 2 showed a cLogP of 0.68 that allowed it to cross the membrane more easily in relation to compound $\mathbf{1}$, which showed a cLogP of 0.62 .

Finally, previous studies have shown that after oral administration, quercetin (compound $\mathbf{1}$ in aglycone form) is biotransformed into 3,4-dihydroxyphenylacetic acid; 3-(3-hydroxyphenyl) propionic acid; 3,4-dihydroxybenzoic acid; and 4-hydroxybenzoic acid (Luca et al. 2020). However, the myricetin (compound $\mathbf{2}$ in aglycone form)

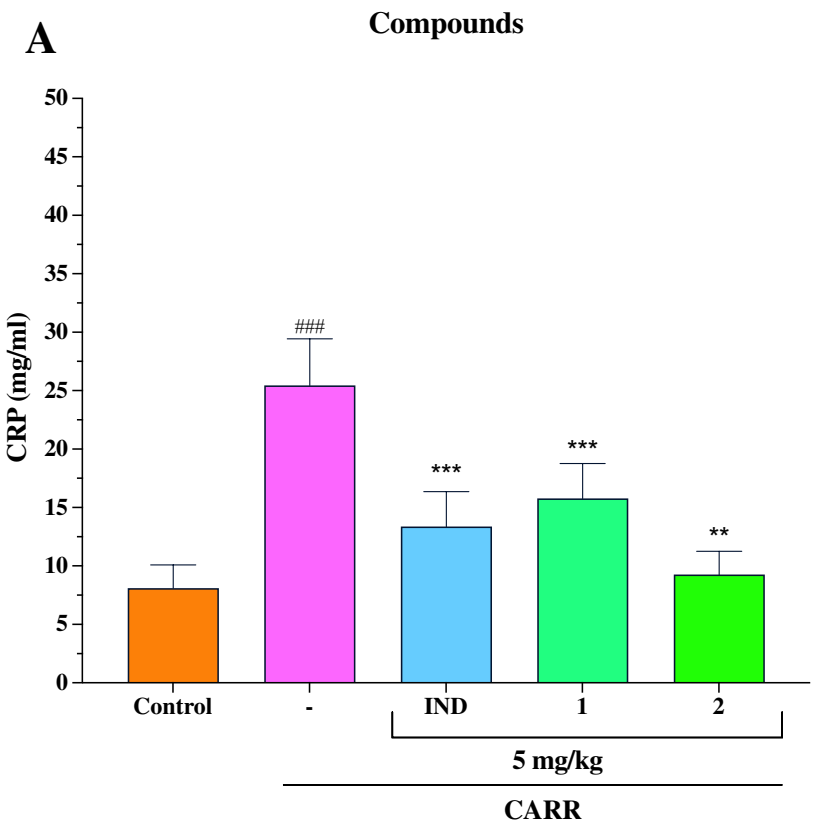

Fig. 7 Study of CRP (C-reactive protein) levels (A) and fibrinogen (B) in mice treated with the quercetin-3-O- $\beta-\mathrm{D}-$ xylofuranosyl-(1 $\rightarrow 2)$ - $\alpha$-L-rhamnopyranoside $(\mathbf{1})$ and myricetin-3- is biotransformed into 3,5-dihydroxyphenylacetic acid; 3,4,5-trihydroxyphenylacetic acid; methylate myricetin; dimethylate myricetin; tetramethylate myricetin; myricetin monoglucuronide; and myricetin diglucuronide (Lin et al. 2012). Therefore, it is necessary to determine if the greater number of compounds derived from the biotransformation of myricetin can generate a greater anti-inflammatory effect in comparison with quercetin.

On the other hand, Antunes-Ricardo et al. (2015) determined that diglycoside flavonoids have greater anti-inflammatory activity (inhibition of NO release) compared to their corresponding triglycosides and aglycones. In our case, compounds $\mathbf{1}$ and $\mathbf{2}$ are linked to the sugars $\beta$-D-xylofuranose and $\alpha$-L-rhamnopyranose. This is the first time that their antiinflammatory activity has been reported.

Finally, regarding the mechanism of action of the two isolated compounds, even if the inhibition of TNF- $\alpha$ is through the downregulation of gene expression for NF- $\mathrm{KB}$, further experiments should be performed to determine whether these compounds can act on other targets by inhibiting inflammatory enzymes, modulating transcription factors and inflammation-related pathways, and reducing NO or ROS accumulation. In relation to the CRP level, this decreased significantly $(* * * p<0.001)$ in the groups treated with the compounds $1(15.77 \mathrm{mg} / \mathrm{ml})$ and $\mathbf{2}(9.26 \mathrm{mg} / \mathrm{ml})$ and IND $(13.37 \mathrm{mg} / \mathrm{ml})$ compared to the CARR group $(25.45 \mathrm{mg} /$ ml) (Fig. 7A). Lastly, with respect the fibrinogen rate, this decreased significantly $(* * * p<0.001)$ in the groups treated with compounds $1(2.86 \mathrm{~g} / \mathrm{l})$ and $2(2.30 \mathrm{~g} / \mathrm{l})$ and IND

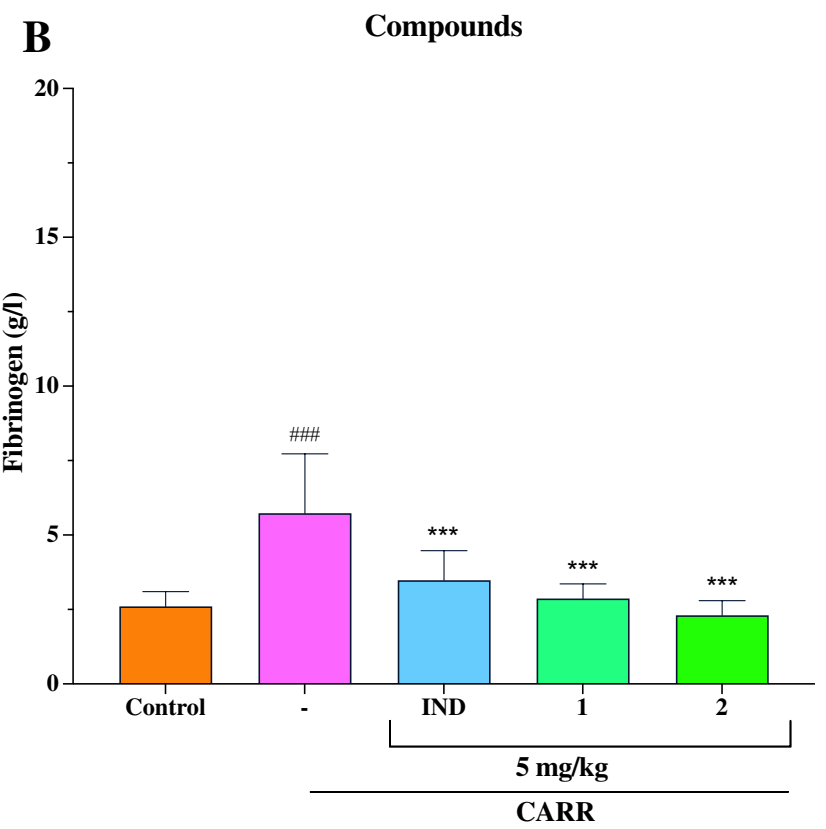

$O$ - $\beta$-D-xylofuranosyl-( $1 \rightarrow 2)-\alpha$-L-rhamnopyranoside (2) compounds from Syzygium jambos by CARR (carrageenan). Values represent the mean $\pm \mathrm{SD}(? ?=6)$ in each group 


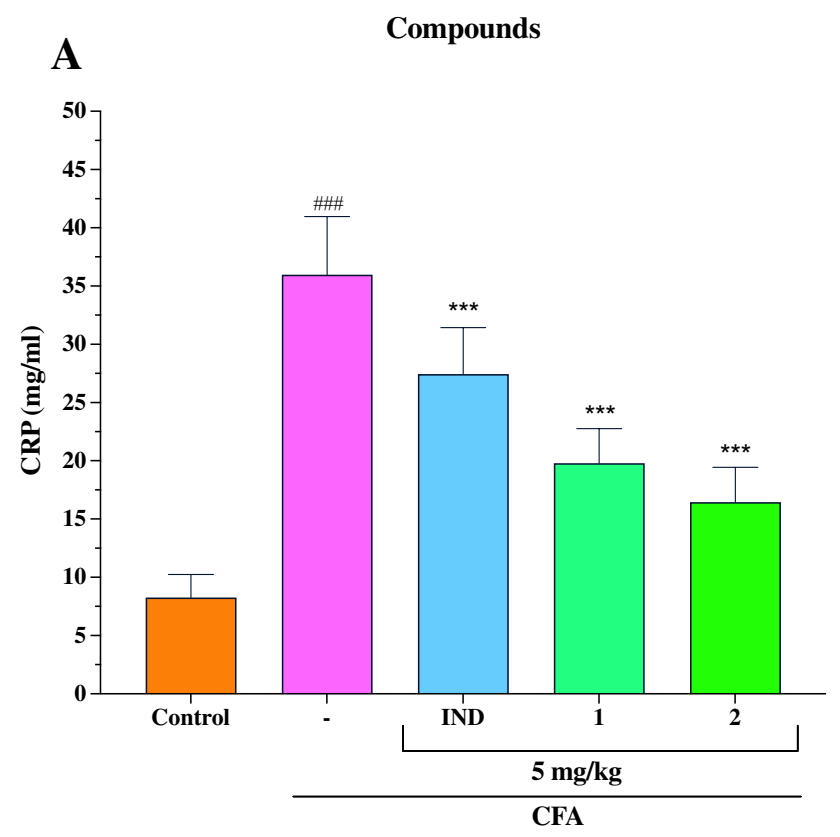

Fig. 8 Study of CRP (C-reactive protein) levels (A) and fibrinogen (B) in mice treated with the quercetin-3-O- $\beta$-Dxylofuranosyl-( $1 \rightarrow 2)$ - $\alpha$-L-rhamnopyranoside (1) and myricetin-3-

(3.48 g/l) when compared to the CARR group (5.73 g/l) (Fig. 7B). Instead, the CRP level decreased significantly $(* * * p<0.001)$ in the groups treated with compounds 1 $(19.77 \mathrm{mg} / \mathrm{ml})$ and $2(16.44 \mathrm{mg} / \mathrm{ml})$ and IND $(27.44 \mathrm{mg} / \mathrm{ml})$ when compared to the CFA group $(35.96 \mathrm{mg} / \mathrm{ml})$ (Fig. 8A). Finally, with respect the fibrinogen rate, this decreased significantly $(* * * p<0.001)$ in the groups treated with compounds $1(12.32 \mathrm{~g} / \mathrm{l})$ and $2(11.44 \mathrm{~g} / \mathrm{l})$ and IND (13.14 g/l) when compared to the CFA group (15.78 g/l) (Fig. 8B).

Hematological changes that occur after the administration of CARR or CFA confirm the resulting acute or chronic inflammation. These changes led to an impressive increase in blood cells and platelets at the site of inflammation due to the release of inflammatory cytokines. Likewise, the inhibition of inflammation in the mice treated with the compounds $(5 \mathrm{mg} / \mathrm{kg})$ is confirmed by the significant decrease in fibrinogen and CRP levels compared to the mice treated with the synthetic drug (IND).

\section{Conclusions}

In conclusion, we found that in assays of short duration, such as carrageenan-induced edema, as well as in assays of longer duration, such as CFA-induced arthritis, the aqueous extract from $S$. jambos at a dose of $5 \mathrm{mg} / \mathrm{kg}$ inhibited significant swelling of the feet of mice. These results suggest that this plant has anti-inflammatory effects on acute experimental arthritis. Similarly, diglycoside

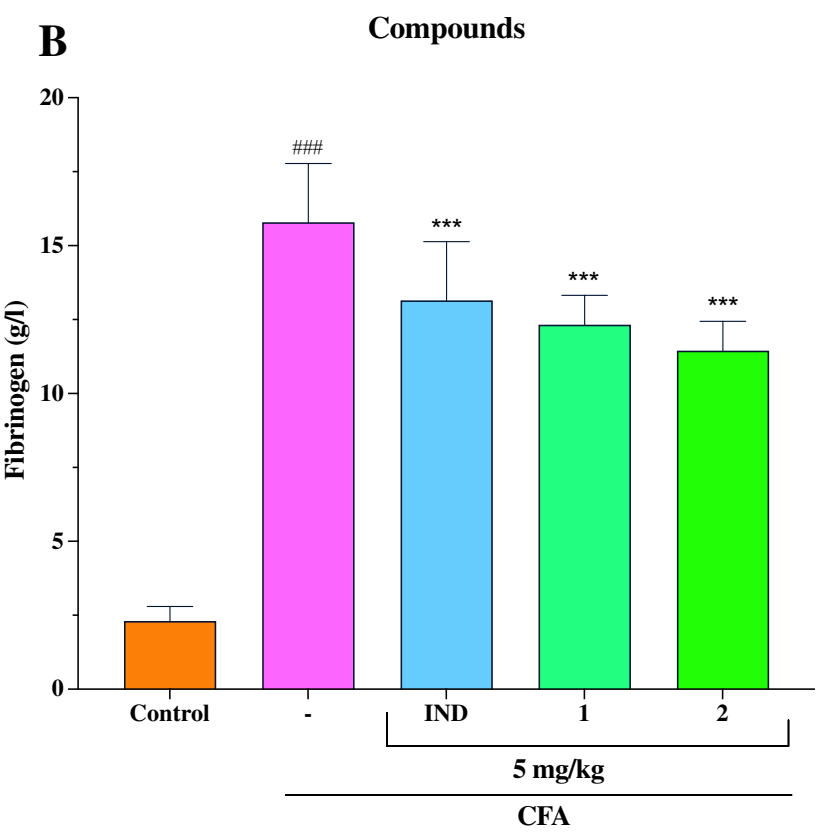

$O$ - $\beta$-D-xylofuranosyl-( $(\rightarrow 2)-\alpha$-L-rhamnopyranoside (2) compounds from Syzygium jambos by CFA (Freund's Complete Adjuvant). Values represent the mean $\pm \mathrm{SD}(? ?=6)$ in each group

flavonoids quercetin-3- $O-\beta$-D-xylofuranosyl- $(1 \rightarrow 2)-\alpha-\mathrm{L}-$ rhamnopyranoside (1) and myricetin-3-O- $\beta$-Dxylofuranosyl-( $1 \rightarrow 2)-\alpha$-L-rhamnopyranoside $(2)$ isolated have a potent suppressive effect in pro-inflammatory responses, proving to be an alternative for the treatment of inflammatory diseases. In this sense, our paper contributes towards the discovery of compounds capable of modulating the activities of TNF- $\alpha$ as possible candidates for the treatment of inflammatory processes.

Supplementary Information The online version contains supplementary material available at https://doi.org/10.1007/s43450-021-00167-0.

Acknowledgements We would like to thank Professors Monica Söllhuber and Emilia Carretero, for their initial support in the investigation of this plant species.

Author Contribution LAT: phytochemical analysis, isolation of compounds; KS: biological experiments, manuscript writing, and figure preparation; BSP and VMA: conception of the study, experiments, and statistical analysis; LAT: writing and editing of the manuscript and the figures. All authors read and approved the final manuscript.

Funding Open Access funding provided thanks to the CRUE-CSIC agreement with Springer Nature. This work was supported by the National Herbarium of Bolivia and the Fundación de la Universidad Autónoma de Madrid (FUAM).

\section{Declarations}

Ethics Approval All studies in this review were in accordance with the Institutional Review Board and Institutional Animal Care and Use Committee procedures. 
Protection of Animal Subjects Experiments reported in this study were performed after approval of protocol no. 127 by the Institutional Ethics Committee of Universidad Autónoma de Madrid on June 13, 2020, and were carried out in accordance with the "Principles of Laboratory Animal Care" from NIH publication 85-23.

Conflict of Interest The authors declare no competing interests.

Open Access This article is licensed under a Creative Commons Attribution 4.0 International License, which permits use, sharing, adaptation, distribution and reproduction in any medium or format, as long as you give appropriate credit to the original author(s) and the source, provide a link to the Creative Commons licence, and indicate if changes were made. The images or other third party material in this article are included in the article's Creative Commons licence, unless indicated otherwise in a credit line to the material. If material is not included in the article's Creative Commons licence and your intended use is not permitted by statutory regulation or exceeds the permitted use, you will need to obtain permission directly from the copyright holder. To view a copy of this licence, visit http://creativecommons.org/licenses/by/4.0/.

\section{References}

Abbasi M, Mousavi MJ, Jamalzehi S, Alimohammadi R, Bezvan MH, Mohammadi H, Aslani S (2019) Strategies toward rheumatoid arthritis therapy; the old and the new. J Cell Physiol 234:1001810031. https://doi.org/10.1002/jcp. 27860

Antunes-Ricardo M, Gutiérrez-Uribe JA, Martínez-Vitela C, SernaSaldívar SO (2015) Topical anti-inflammatory effects of isorhamnetin glycosides isolated from Opuntia ficus-indica. BioMed Res Int 2015:847320. https://doi.org/10.1155/2015/847320

Apaza Ticona L, Serban AM, Apaza Ticona D, Slowing K (2021) Anti-inflammatory and anti-arthritic activities of aqueous extract and flavonoids from Tripodanthus acutifolius leaves in mice paw oedema. Planta Med Int Open 8:e43-e55. https://doi.org/10. 1055/a-1471-8947

Bezerra AN, Massing LT, de Oliveira RB, Mourão RH (2017) Standardization and anti-inflammatory activity of aqueous extract of Psittacanthus plagiophyllus Eichl. (Loranthaceae). J Ethnopharmacol 202:234-240. https://doi.org/10.1016/j.jep.2017.03.029

Castejón D, Fricke P, Cambero MI, Herrera A (2016) Automatic ${ }^{1} \mathrm{H}-$ NMR screening of fatty acid composition in edible oils. Nutrients 8:93. https://doi.org/10.3390/nu8020093

Chua LK, Lim CL, Ling A, Chye SM, Koh RY (2019) Anticancer potential of Syzygium species: a review. Plant Foods Hum Nutr 74:18-27. https://doi.org/10.1007/s11130-018-0704-z

de Paulo FD, Neri-Numa IA, de Araújo FF, Pastore GM (2020) A critical review of some fruit trees from the Myrtaceae family as promising sources for food applications with functional claims. Food Chem 306: 125630. https://doi.org/10.1016/j.foodchem. 2019.125630

di Gesso JL, Kerr JS, Zhang Q, Raheem S, Yalamanchili SK, O'Hagan D, Kay CD, O'Connell MA (2015) Flavonoid metabolites reduce tumor necrosis factor- $\alpha$ secretion to a greater extent than their precursor compounds in human THP-1 monocytes. Mol Nutr Food Res 59:1143-1154. https://doi.org/10.1002/mnfr.201400799

Doss HM, Ganesan R, Rasool M (2016) Trikatu, an herbal compound ameliorates rheumatoid arthritis by the suppression of inflammatory immune responses in rats with adjuvant-induced arthritis and on cultured fibroblast like synoviocytes via the inhibition of the NF- $\mathrm{KB}$ signaling pathway. Chem-Biol Interact 258:175-186. https://doi.org/10.1016/j.cbi.2016.09.003
Farzaei MH, Singh AK, Kumar R, Croley CR, Pandey AK, CoyBarrera E, Kumar Patra J, Das G, Kerry RG, Annunziata G, Tenore GC, Khan H, Micucci M, Budriesi R, Momtaz S, Nabavi SM, Bishayee A (2019) Targeting inflammation by flavonoids: novel therapeutic strategy for metabolic disorders. Int J Mol Sci 20:4957. https://doi.org/10.3390/ijms20194957

Friedman B, Cronstein B (2019) Methotrexate mechanism in treatment of rheumatoid arthritis. Jt Bone Spine 86:301-307. https://doi.org/ 10.1016/j.jbspin.2018.07.004

Gomes RP, Bressan E, Silva TM, Gevaerd Mda S, Tonussi CR, Domenech SC (2013) Standardization of an experimental model suitable for studies on the effect of exercise on arthritis. Einstein 11:76-82. https://doi.org/10.1590/s1679-45082013000100014

Haque M, Begum MM, Hasan M, Towheedur Rahman AFM, Hussain MI, Mizanur Rahman M, Ali MH, Islam MA, Sultan MZ, Reyadul-Ferdous M, Hasan CM (2015) Investigation of the medicinal potentials of Syzygium jambos (L.) extract and characterization of the isolated compounds. Am J BioSci 3:12-18. https://doi.org/10. 11648/j.ajbio.s.2015030201.13

Harth M, Nielson WR (2019) Pain and affective distress in arthritis: relationship to immunity and inflammation. Expert Rev Clin Immunol 15:541-552. https://doi.org/10.1080/1744666X.2019. 1573675

Hossain H, Rahman SE, Akbar PN, Khan TA, Rahman MM, Jahan IA (2016) HPLC profiling, antioxidant and in vivo anti-inflammatory activity of the ethanol extract of Syzygium jambos available in Bangladesh. BMC Res Notes 9:191. https://doi.org/10.1186/ s13104-016-2000-z

Kuprash DV, Nedospasov SA (2016) Molecular and cellular mechanisms of inflammation. Biochem Biokhimiia 81:1237-1239. https://doi.org/10.1134/S0006297916110018

Lin Y, Wu B, Li Z, Hong T, Chen M, Tan Y, Jiang J, Huang C (2012) Metabolite identification of myricetin in rats using HPLC coupled with ESI-MS. Chromatographia 75:655-660. https://doi.org/10. 1007/s10337-012-2239-Z

Luca SV, Macovei I, Bujor A, Miron A, Skalicka-Woźniak K, Aprotosoaie AC, Trifan A (2020) Bioactivity of dietary polyphenols: the role of metabolites. Crit Rev Food Sci Nutr 60:626-659. https:// doi.org/10.1080/10408398.2018.1546669

Makni S, Tounsi S, Rezgui F, Trigui M, Bouassida KZ (2019) Emex spinosa (L.) Campd. ethyl acetate fractions effects on inflammation and oxidative stress markers in carrageenan induced paw oedema in mice. J Ethnopharmacol 234:216-224. https://doi.org/ 10.1016/j.jep.2018.12.015

Merkx DWH, Westphal Y, van Velzen EJJ, Thakoer KV, de Roo N, van Duynhoven JPM (2018) Quantification of food polysaccharide mixtures by 1H NMR. Carbohydr Polym 179:379-385. https:// doi.org/10.1016/j.carbpol.2017.09.074

Puxeddu I, Caltran E, Rocchi V, Del Corso I, Tavoni A, Migliorini P (2016) Hypersensitivity reactions during treatment with biological agents. Clin Exp Rheumatol 34:129-132

Rha CS, Jeong HW, Park S, Lee S, Jung YS, Kim DO (2019) Antioxidative, anti-inflammatory, and anticancer effects of purified flavonol glycosides and aglycones in green tea. Antioxidants 8:278. https://doi.org/10.3390/antiox8080278

Rocchetti G, Lucini L, Ahmed SR, Saber FR (2019) In vitro cytotoxic activity of six Syzygium leaf extracts as related to their phenolic profiles: an untargeted UHPLC-QTOF-MS approach. Food Res Int 126:108715. https://doi.org/10.1016/j.foodres.2019.108715

Ruiz PA, Braune A, Hölzlwimmer G, Quintanilla-Fend L, Haller D (2007) Quercetin inhibits TNF-induced NF-kappaB transcription factor recruitment to pro-inflammatory gene promoters in murine intestinal epithelial cells. J Nutr 137:1208-1215. https://doi.org/ 10.1093/jn/137.5.1208

Shen SC, Lee WR, Lin HY, Huang HC, Ko CH, Yang LL, Chen YC (2002) In vitro and in vivo inhibitory activities of rutin, wogonin, 
and quercetin on lipopolysaccharide-induced nitric oxide and prostaglandin E2 production. Eur J Pharmacol 446:187-194. https://doi.org/10.1016/s0014-2999(02)01792-2

Slowing K, Sõllhuber M, Carretero E, Villar A (1994) Flavonoid glycosides from Eugenia jambos. Phytochemistry 37:255-258. https:// doi.org/10.1016/0031-9422(94)85036-4

Sobeh M, Esmat A, Petruk G, Abdelfattah MAO, Dmirieh M, Monti DM, Abdel-Naime AB, Wink M (2018) Phenolic compounds from Syzygium jambos (Myrtaceae) exhibit distinct antioxidant and hepatoprotective activities in vivo. J Funct Foods 14:223-231. https://doi.org/10.1016/j.jff.2017.12.055

Tena Pérez V, Apaza Ticona L, Serban AM, Acero GJ, Rumbero Sánchez A (2020) Synthesis and biological screening of a library of macamides as TNF- $\alpha$ inhibitors. RSC Med Chem 11:11961209. https://doi.org/10.1039/D0MD00208A
Udalova I, Monaco C, Nanchahal J, Feldmann M (2016) Anti-TNF Therapy Microbiol Spectr 4:10. https://doi.org/10.1128/micro biolspec.MCHD-0022-2015

Wang L, Tu YC, Lian TW, Hung JT, Yen JH, Wu MJ (2006) Distinctive antioxidant and anti-inflammatory effects of flavonols. J Agric Food Chem 54:9798-9804. https://doi.org/10.1021/jf0620719

Ye H, Wang Y, Jenson AB, Yan J (2016) Identification of inflammatory factor TNF- $\alpha$ inhibitor from medicinal herbs. Exp Mol Pathol 100:307-311. https://doi.org/10.1016/j.yexmp.2015.12.014

Zelová H, Hošek J (2013) TNF- $\alpha$ signaling and inflammation: interactions between old acquaintances. Inflamm Res 62:641-651. https://doi.org/10.1007/s00011-013-0633-0 